\title{
Landuse Planning for Food Crop Areas Development Using Land Resource Evaluation Approach and GIS Application (a Case Study of Pulang Pisau District, Central Kalimantan Province)
}

\author{
Perencanaan Penggunaan Lahan untuk Pengembangan Kawasan Tanaman Pangan \\ Menggunakan Pendekatan Evaluasi Sumberdaya Lahan dan Aplikasi GIS \\ (Studi Kasus Kabupaten Pulang Pisau, Provinsi Kalimantan Tengah) \\ Sri Agustini $\left.{ }^{1 *}\right)$, Suparman Suparman ${ }^{1}$, and Hia Cinta Tridamayanti ${ }^{2}$

\footnotetext{
${ }^{1}$ Researcher at Assessment Institute for Agricultural Technology (AIAT) of Central Kalimantan
} \\ ${ }^{2}$ Extension Agent at Assessment Institute for Agricultural Technology (AIAT) of Central Kalimantan \\ ${ }^{*)}$ Corresponding author: andybhermana@yahoo.com
}

(Received 10 February 2020, Accepted 27 March 2020)

Citation: Agustini S, Suparman S, Tridamayanti HC. 2020. Landuse planning for food crop areas development using land resource evaluation approach and gis application (a case study of Pulang Pisau District, Central Kalimantan Province). Jurnal Lahan Suboptimal: Journal of Suboptimal Lands 9(1): 64-72.

\begin{abstract}
ABSTRAK
Dalam rangka mewujudkan penggunaan lahan yang berkelanjutan, maka perencanaan penggunaan lahan yang dirancang berdasarkan pengelolaan data sumberdaya lahan secara kewilayahan sangat diperlukan. Evaluasi sumberdaya lahan merupakan komponen utama di dalam perencanaan penggunaan lahan sebagai prosedur yang dapat diaplikasikan untuk menentukan kawasan lahan bagi pengembangan usahatani padi. Penggunaan teknologi sistem informasi geografis (GIS) juga dimanfaatkan selain untuk pengelolaan data spasial juga untuk membantu dalam pengambilan keputusan terkait perencanaan penggunaan lahan. Tujuan dari kajian ini adalah untuk menetapkan alokasi penggunaan lahan untuk kawasan ekstensifikasi dan intensifikasi dalam pengembangan komoditas tanaman pangan sebagai bagian utama dalam perencanaan penggunaan lahan. Dalam studi kasus di Kabupaten Pulang Pisau, alokasi lahan untuk kawasan ekstensifikasi dan intensifikasi sebagain besar terdapat di bagian selatan yaitu pada daerah-daerah aliran sungai dengan luas masing-masing 380.261 hektar (36.81\%) dan 29.941 hektar $(2.90 \%$ dari total luas wilayah Kabupaten Pulang Pisau). Selanjutnya, dukungan berupa program-program khusus dapat disusun dalam rangka peningkatan hasil dan produktivitas untuk usahatani padi khususnya kawasan-kawasan potensial tersebut.
\end{abstract}

Kata kunci: alokasi lahan, lahan pertanian, pengelolaan, data, Kabupaten Pulang Pisau

\begin{abstract}
In order to promote sustainable landuse, the need of landuse planning is urgently required and it can be designed based on the result of spatial land resource data management. Land resource evaluation is main component for landuse planning which this procedure was applied to determine land allocation for arable lands for rice farming development. The use of geographic information system (GIS) technology was also employed not only for spatial data management, but they could also be applied to support decision making within establishing landuse planning. The objective of this study was to
\end{abstract}


allocate the arable lands for extensification and intensification regions as main part of landuse planning for food crops areas development. In the case of Pulang Pisau District, land allocation for extensification and intensification regions were mainly found in southern part and mostly located at watershed areas with each total areas respectively of 380,261 hectares $(36.81 \%)$ and 29,941 hectares $(2.90 \%$ of total areas of Pulang Pisau District). In order to support these potential areas, specific programs could then be formulated to increase the yield and productivity for these regions.

Keywords: land allocation, arable lands, data, management, Pulang Pisau district

\section{INTRODUCTION}

The need of landuse planning is urgently required in order to achieve sustainable agicuture. This reasonable because not all the lands can be optimally utilized depending on their land potential and suitability (Djaenudin, 2009). In the scoupe of management, landuse planning can implemented to help identify the most appropriate land uses for specified purposes (http://www.fao.org/3/CA0827EN/ca0827e n.pdf).

Several programs established by Indonesian government have been implemented in order to achive Indonesia's food self-suffiency and food security as weel (Mulyani and Agus, 2017). One of several food crops that has been established by local government as foccussed program for food self-suffiency and food security included rice. Therefore, the goals of this program should be supported through proper land utilization. In Central Kalimantan, some efforts that have been conducted involve intensification and extensification program for increasing rice productivity. In addition to intensification, land expansion as part of extensification program can be implemented because of the availability of land resources. Information taken from BPS-Statistics of Central Kalimantan Province (2019) stated that at regional scale, by the end of 2018, total area of rice farming is 202,142 hectares or only $1.31 \%$ of total areas of Central Kalimantan province and this indicate that land potency based on areas is still available.

Land use planning is then required in order to achieve proper land use because since the land is utilized improperly, productivity rapidly decreases and the ecosystems become jeopardized (Amien, 1998). As part of land use planning, land evaluation approach can be used in order to identify and recognize lands for specified purposes (Ritung et al., 2007; Basic et al., 2003; Arshad, 1999; Abdullah, 1993).

The need for land resources evaluation become apparent when the region has an opportunity to be developed and decisions on land use have always been part of the evolution of human society. By assessing land resources for alternative uses relative to the land - related requirements or goals of society, it should be possible to identify certain areas which are strategically important for particular activities (Bhermana et al., 2013).

Geographic Information System (GIS) become an effective tool for agricultural development since spatial data has important role and essential factor for farming practice. It can provide valuable information related to spatial data to assist land use planning (Yousefi and Razdari, 2015). The use of GIS technology can be employed not only for spatial data management, but they can also be applied to support decision making (Jitendra et al., 2016; Agatsiva and Oroda, 2002). In this study, this technology can be applied to generate baseline information of land resource as basic spatial analysis for land use planning. Spatial concepts for land use planning involving land allocation for agriculture can then be planned and performed accuratelly (Bhermana et al., 2013). It can support regional development policy and common agricultural policy (Alexiadis et al., 2013). The objective of this study was to identify the lands based on 
land suitability for rice and existing standing crop of rice as basic information and consideration of land use planning for food crops areas development.

\section{MATERIALS AND METHODS}

This study was conducted in 2019 and focussed on existing areas of rice in Pulang Pisau regency. Based on pre eliminary study, administratively, total areas of study cover almost 1,033,122 hectares (Figure 1). Initial procedure used in this study include land evaluation in order to determine land suitability for rice as part of food crops. This methods used procedure of matching between land quality/characteristics and crop requirement for rice (BBSDLP, 2016; Siswanto, 2006; Sys et al., 1993). The result of land resources evaluation as main component for land use planning process was conducted on the basis of information at semi-detailedlevel with scale of 50, 000 .
This level refers to guidelines provided by Indonesian Government Regulation No. 100/2000 about mapping scales for spatial land use planning. The GIS technology were applied as computer-based tool for mapping and analyzing feature events on earth (ESRI, 2012). In this study, remote sensing (RS) technology was also employed to survey and monitor bio-resource features (Menon, 2012). In this study, it was then used to provide land cover information especially for standing crop of rice (Townshend et al., 1991). While for the GIS, it was applied to integrate the RS's data and the result $\mathrm{s}$ of land evaluationas part of mapping process for further spatial analysis. Several usefull tolls used in this study include ER Mapper 7.0 and Arc Gis 10.1 software. These tools was employed to organize dan manage spatial data while at the same time, they can also used to assist spatial analysis.

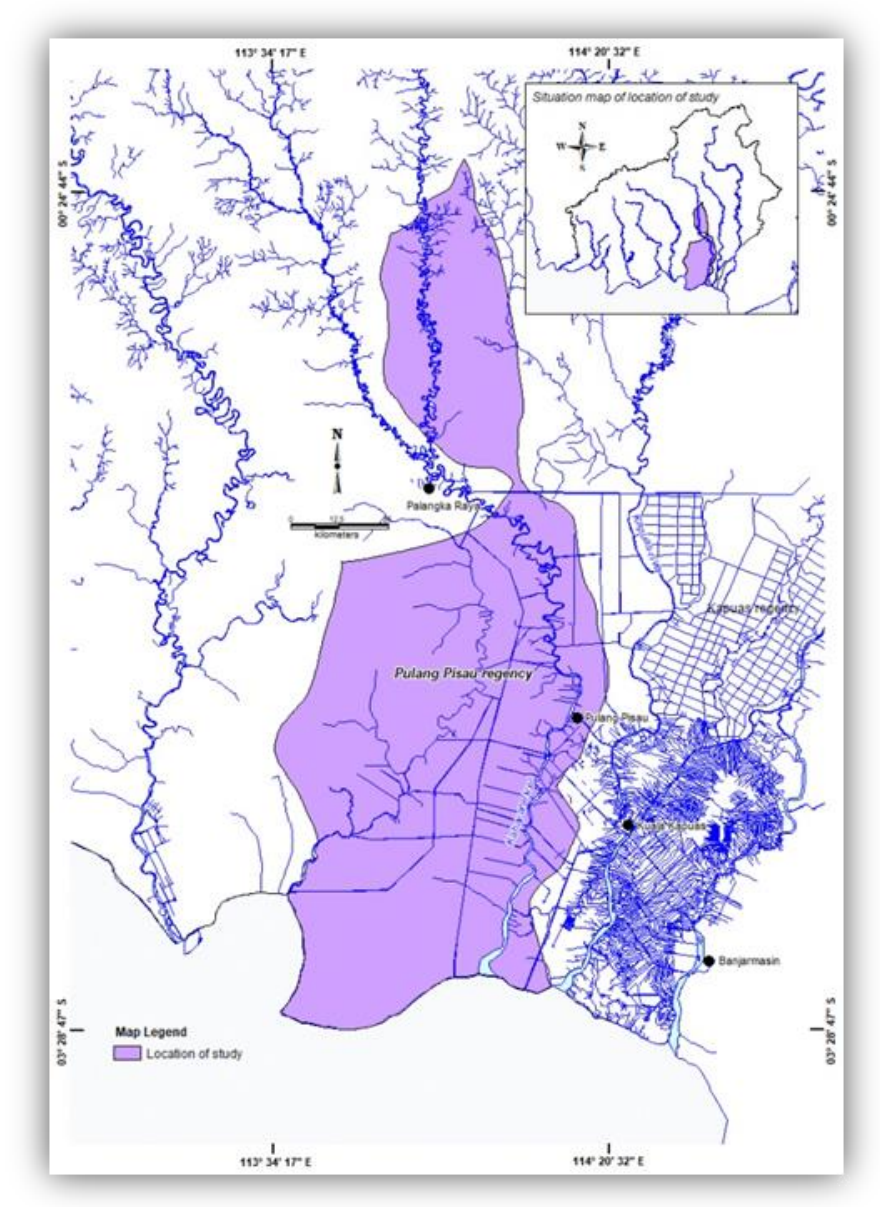

Figure 1. General situasion map of study location 


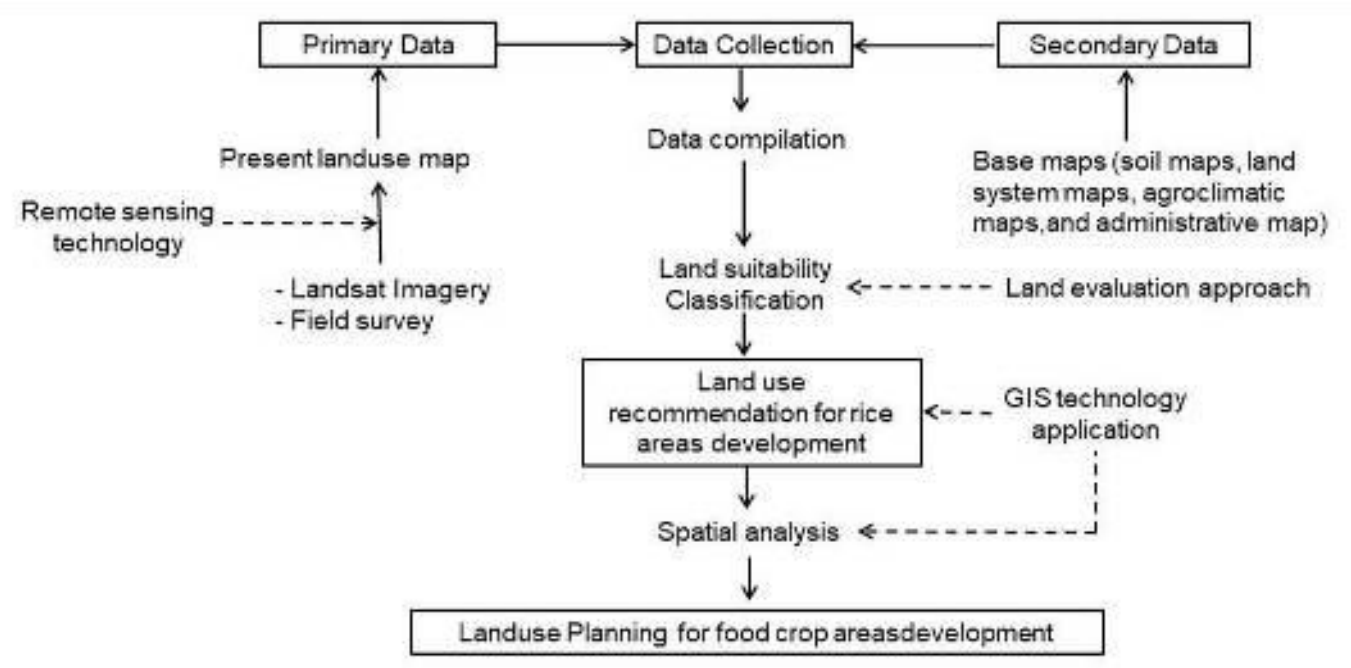

Figure 2. Flowchart of general procedure in this study

Materials required in this study included several base maps consiting of soil maps, land system maps, agroclimatic maps, topographical maps and administrative maps. Primary data of land cover as RS's data was accessed from Landsat 8. For field verification the GPS device was used to identify land cover and to compare between the resulting maps that have been produced and real condition in the field. The general procedure of this study was described at Figure 2.

\section{RESULTS AND DISCUSSION}

\section{Land Resources Information}

Pulang Pisau district is situated between $00^{\circ} 24^{\prime} 44^{\prime \prime}$ and $03^{\circ} 28^{\prime} 47^{\prime \prime}$ South latitude and $113^{\circ} 34^{\prime} 17^{\prime \prime}$ and $114^{\circ} 20^{\prime} 32^{\prime \prime}$ East longitude (Figure 1). This region is mainly divided into 2 land typology i.e wetlands and drylands. Wetlands areas is mainly found in the southern part and covered by tidal swamplands and peatlands dominantly. This region is characterized by high soil acidity and low soil fertility (Noor et al., 2014). While for drylands, they occupy in the north and also have low soil fertility due to high leaching and low organic matter content (Prasetyo and Suriadikarta, 2006).

The base maps of soil and land system informed that this study areas consist primarily of mineral and organic soils. Several major soil tipes in study areas include Inceptisols, Entisols, Spodosols and Histosols. The organic soils is mailnly found in the southern part of Pulang Pisau district where many rice farming activities has been existed. Based on field observation, mineral soils was mainly found in the northern parts, while in the south, they are located at watersheds areas as alluvil soils and the other regions as sandy soils.

The climate of Central Kalimantan province where Pulang Pisau district lies on is determined by its geographical position on the equator. Geographically, it is considered as wet equatorial climates that occur mainly within $5^{\circ}$ north and south of the equator. It is dominated during most of the year by deep, moist, equatorial air masses and frequent heavy convectional rainfall (Webster and Wilson, 1980). The wet monsoon usually starts from October to March, while dry monsoon occurs on April to September (Oka, 1982).

By the end of 2018, based on the last ten years record, annual precipitation of this region is $2449 \mathrm{~mm}$ to $3229 \mathrm{~mm}$. Period ofconsecutivewet monthsrangedbetween1012 monthswhile drymonths occur between02months. The highprecipitation is influenced by temperature resulting in high evaporation intensity, causing watersaturated air conditions and potentially active raincloud. For soil temperature and moisture regime, they have fairly 
homogeneous conditions for each climatic regime.

Since the elevation of the whole areas of these district is less than 700 meters above sea level, the temperature regim is isohyperthermic, while moisture regime is udic in which the number of consecutive dry months is less than 3 months per year. The general information of soil and climate is then be used as basic analysis for land use planning for food crops development.

\section{Present Land Use for Food Crops}

The information of present land use was conducted through identification of standing crop. The application of RS was then used based on its capability to understand the global and physical processes affecting the earth (Mallupattu and Reddy, 2013). The RS' technology was employed to interpret land cover information based satellite imagery accessed from Landsat 8.

The data of standing crop for rice based on coverage areas was spatially integrated into GIS environment in order to provide further information about present landuse for rice specifically (Figure 3). The result of spatial analysis indicate that standing crop areas for rice was mainly found in watershed areas where they have been cultivated at alluvial and peatland areas with total areas of 29,941 hectares or $2.90 \%$ of total areas of Pulang Pisau district. Especially for peatlands, these areas can be considered as the subject to land use pressures including agriculture (Jaya et al., 2010). For management, they can be allocated for intensification areas because of the existence of rice farming that has been carried out since along time ago not only by local people but also managed by immigrants.

\section{Determination of Arable Lands for Rice Farming Development}

Land suitability evaluation approach was then used in order to determine arable land for food crop especially rice. The macthing procedure between crop requirement and land characteristics lead to the conclusion that arable lands for rice farming have land suitability class S3 (marginally suitable) at reconaisance level. There are several limiting factors determined based on land evaluation such as slope, nutrient retention, oxigen availability, soil acidity, and peat depth. These indicate that the lands should managed appropriately in order to produce optimum yields. For optimum growth, especially for rice, it require $\mathrm{pH}$ with neutal conditon, optimum water holding capacity and sufficient water with flat condition of relief for soil surface in order to allow balanced water distribution.

The result of land evaluation was then integrated into GIS environment in order to provide spatial pattern of arable land that represent land suitability for rice. It can then be used as basic consideration as land use recommendation for rice development. Based on spatial analysis, it showed that arable lands for rice farming development were located along the river streams and mostly found in the southern parts with total areas 410,202 hectares or $39.71 \%$ of total areas of Pulang Pisau district (Figure 4).

\section{Land Use Planning for Rice Farming Development}

Land use planning can be used to find sustainable land management (Metternicht, 2017). In order to promote sustainable land use, recommendation of proper land allocation can be designed based on the result of spatial land resource data management. In this study, spatial data that have been produced is then further analyzed using overlay technique within GIS environment.

This technique is capable to create composite maps by combining diverse data sets (Yeniguna and Ruken, 2013). For mapping process, this technique play a central role in many GIS applications because of its simplicity for the implementation in vector and raster GIS (O'Sullivan and Unwin, 2003). In this study, for analytical operation, it required 
data layers to be joined physically including the map of present landuse for rice, arable land for rice and administration. The resulting map produced provide new map with new delineated homogeneous polygons that represent delineation areas for extensification and intensification. As a results, based on spatial analysis, the arable lands for rice farming can then be divided into 2 regions i.e. extensification and intensification. Land allocation of these regions are found in the southern part where mostly located in watershed areas. Extensification regions are arable lands where suitable for rice but they have not been culticated and they are considered as lands potential for future development with total areas of 380,261 hectares or $36.81 \%$ of total areas of Pulang Pisau district. While for intensification regions, they located at arable where the lands have been cultivated for rice faming with total areas of 29,941 hectares or $2.90 \%$ (Figure 5). Specific programs such as technologies specific to location can then be formulated in order to increase the yield and productivity for these regions.

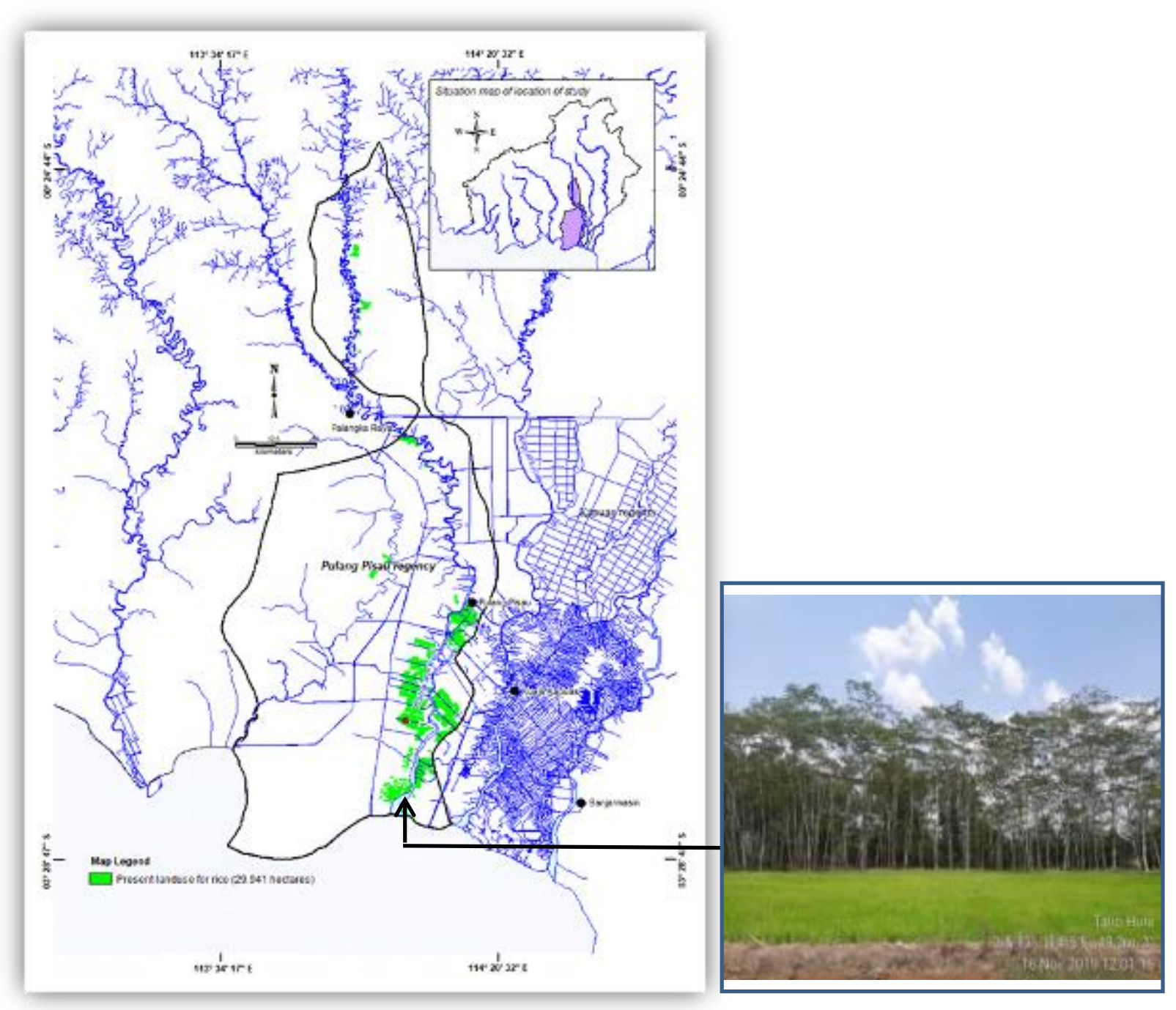

Figure 3. The map of present landuse for rice (left) and standing crop for rice at one of ground check points (right) 


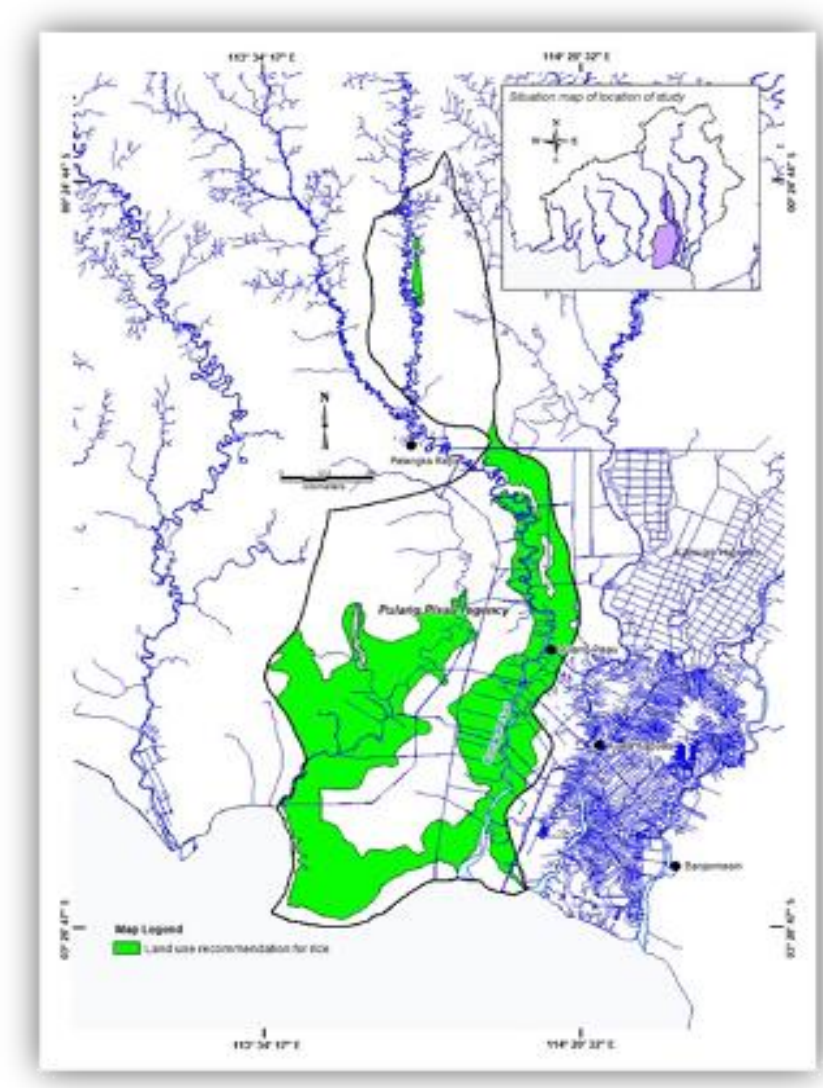

Figure 4. The arable lands for rice farming development in Pulang Pisau district, (marked with green zones)

\section{CONCLUSION}

In order to promote sustainable land use, landuse planning can be designed based on the result of spatial land resource data management. The application of GIS can be employed to manage and analyze spatial data for specified purposes.The overlay tehcnique and visual analysis within GIS environment can be implemented to provide new spatial information as basic consideration for landuse planning. In the case study of Pulang Pisau district, landuse planning for rice farming development has been established through land allocation for extensification and intensification regions with each total areas respectively of 380,261 hectares $(36.81 \%)$ and 29,941 hectares ( $2.90 \%$ of total areas of Pulang Pisau district). In order to support these potential areas, specific programs can then be formulated to increase the yield and productivity for these regions.

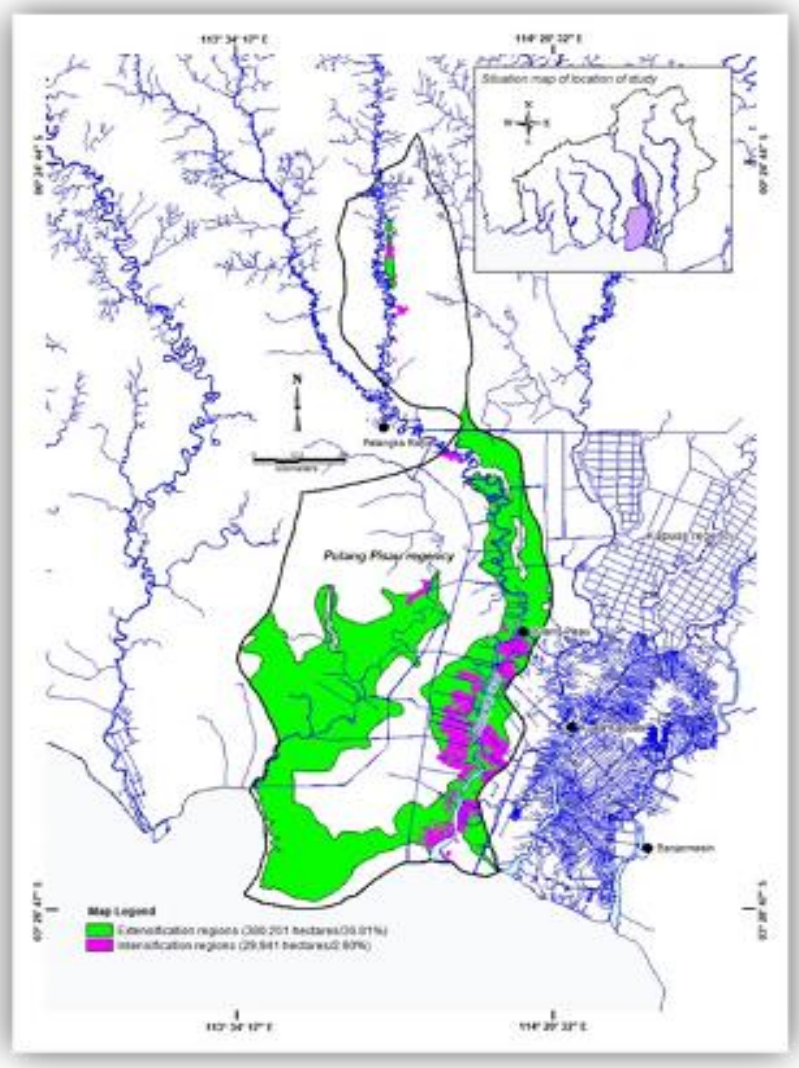

Figure 5. Spatial landuse planning for rice farming development in Pulang Pisau district (marked with green color for extensification areas and violet color for intensive areas)

\section{ACKNOWLEDGEMENT}

The authors would like to thank Dr. Andy Bhermana, SP., MSc as researcher at Assessment Institute for Agricultural Technology (AIAT) of Central Kalimantan for advice and any guidance in writing of this manuscript including analyzing spatial data.

\section{REFERENCES}

Abdullah TS. 1993. Survai Tanah Dan Evaluasi Lahan. Penebar Swadaya. Jakarta.

Agatsiva J, Oroda A. 2002. Remote Sensing and GIS in the Development of a Decision Support System for Sustainable Management of the Drylands of Eastern Africa: A Case of the Kenyan Drylands. The International Archives of the Photogrammetry, 
Remote Sensing and Spatial Information Sciences, Vol. XXXIV, Part 6/W6.

Alexiadis S, Ladias C, Hasanagas N. 2013. A regional perspective of the Common Agricultural Policy. Land Use Policy. 30: 665-669.

Amien LI. 1998. An Agroecological Approach to Sustainable Agriculture. In: El-Swaify S. A. and Yakowitz D. S. (Editors). Multiple Objective Decision making for land, Water, and Environmental Management. Proceeding of the $1^{\text {st }}$ International Conference on Multiple Objective Decision Support Systems (MODSS) for Land, Water, and Environmental Management; Concepts, Approaches, and Applications. Lewis Publisher: 465-480.

Arshad ABM. 1999. Land Evaluation fo Elaeis Guineensis Jacq. Cultivation in Peninsular Malaysia. Ph.D Thesis. University Putra Malaysia.

Basic LLZ,. Rossiter DG, Bregt AK. 2003. The Use of Land Evaluation Information by Land Use Planners and Decisionmakers: a case study in Santa Catarina, Brazil. Soil Use and Management. (19): 12-8.

BBSDLP. 2016. Pedoman Penilaian Kesesuaian Lahan untuk Komoditas Pertanian Strategis. Petunjuk Teknis. Balai Besar Sumberdaya Lahan Pertanian. Badan Litbang Pertanian.

BPS-Statistics of Central Kalimantan Province. 2019. Kalimantan Tengah Province In Figure. (759 pages).

Bhermana A, Sunarminto BH, Utami SNH, Gunawan T. 2013. The Combination of Land Resource Evaluation Approach and GIS Application to Determine Prime Commodities for Agricultural Land Use Planning At Developed Areas. (a Case Study of Central Kalimantan Province, Indonesia). ARPN Journal of Agricultural and Biological Science. 8(12): 1-14.

Djaenudin D. 2009. Prospek Penelitian Potensi Sumberdaya Lahan di Wilayah Indonesia. Journal Pengembangan Inovasi Pertanian. 2(4): 243-257.
ESRI. 2012. GIS for National Mapping. An Esri White Paper, June, 2012.

Jaya A, Takashi I, Limin SH, Darung U, Irwan SB. 2010. Microclimate of Developed Peatland of the Mega Rice Project in Central Kalimantan. J Trop Soils. 15(1): 63-71.

Jitendra S, Krishna Kumar Y, Neha G, Vinit K. 2016. Remote Sensing and Geographical Information System (GIS) and Its Applicationn in Various Fields. In: Rakesh Sohal (Editor). Proceedings of National Conference on Energy and Environment: 158-178.

Mallupattu PK, Reddy JRS. 2013. Analysis of Land Use/Land Cover Changes Using Remote Sensing Data and GIS at an Urban Area, Tirupati, India. The ScientificWorld Journal Volume 2013, Article ID 268623 (6 pages).

Menon ARR. 2012. Remote Sensing Application in Agriculture and Forestry. In: T Sabu, T., Vinod. T R., M Subramonia, I., C. Bhaskaran., and B. Ambat (Editors). Proceedings of the Kerala Environment Congress, 2012: 222-235.

Metternicht G. 2017. Land Use Planning. Global Land Outlook (Working Paper). September 2017.

Mulyani A, Agus F. 2017. Kebutuhan dan Ketersediaan Lahan Cadangan Untuk Mewujudkan Cita-Cita Indonesia Sebagai Lumbung Pangan Dunia tahun 2045. Analisis Kebijakan Pertanian. 15(1):1-17.

Noor M, Masganti, Fahmuddin A. 2014. Pembentukan dan Karakteristik Gambut Tropika Indonesia. Lahan Gambut Indonesia. Pembentukan, Karakteristik, dan Potensi Mendukung Ketahanan Pangan (Edisi Revisi): 7-32.

Prasetyo BH, Suriadikarta. DA. 2006. Karakteristik, Potensi, dan Teknologi Pengelolaan Tanah Ultisols Untuk Pengembangan Pertanian Lahan Kering di Indonesia. Jurnal Litbang Pertanian. 25(2): 39-46.

Ritung S, Wahyunto F, Agus, Hidayat H. 2007. Land Suitability Evaluation. with 
a Case Map of Aceh Barat District. Guidelines. Indonesian Soil Research Institute and World Agroforestry Centre.

Siswanto. 2006. Evaluasi Sumberdaya Lahan. Penerbit UPN Press. (120 pages). Townshend J, Christopher J, Wei Li, Charlotte G, McManus J. 1991. Global land cover classification by remote sensing: present capabilities and future possibilities. Remote Sensing of
Environment. 35(2):243-255.

Yeniguna K, Ruken E. 2013. Overlay mapping trend analysis technique and its application in Euphrates Basin, Turkey. Meteorological. Applications. 20:427438.

Yousefi MR, Razdari AM. 2015. Application of Gis and Gps in Precision Agriculture (a Review). Int. J. Adv. Biol. Biom. Res. 3(1): 7-9. 